\title{
Improving Student's Reading Comprehension on Narrative Text Through Directed Reading Think Pair Share (TPS) at Madrasa Aliyah
}

\author{
Alfi Nikmah ${ }^{1}$ \\ ${ }^{1}$ Institut Agama Islam Negeri Kudus, Kudus, Indonesia \\ @ alfi10@iainkudus.ac.id
}

\begin{abstract}
The purpose of the research was to find out the improvement of student's reading comprehension on narrative text through directed reading and think pair share at madrasa Aliyah of Manahijul Huda Ngagel in academic years 2019/2020. This research was done by applying Classroom Action Research which carried out through four steps. They were planning, action, observation, and reflection, in cycle 1 and cycle 2 . The subject of research was the grade X-MIA, they are consisted of 30 students. Based on the result of the data analysis showed that mean of the score has increased in the cycle 2, the mean in the pre-test was $63,33 \%$, the mean of cycle 1 was $74,33 \%$. Then the mean of cycle 2 was $84,17 \%$. The students who got up 75 also grew up. In the pretest, students who got up 75 were only 5 of 30 students $(16,67 \%)$. In the post test of cycle 1, students who got up 75 were only 17 of 30 students $(56,67 \%)$. It means that there was improvement about $40 \%$. In the post test of cycle 2, students who got up 75 were 24 of 30 students (80\%). The improvement was about $23,33 \%$. The total improvement of the student's score from the pre-test to post test of cycle 2 was $63,33 \%$. So, the result of the research showed that Directed-reading and Think Pair Share (TPS) strategy significantly improved student's reading comprehension on narrative text.
\end{abstract}

KEYWORDS:

Directed reading, narrative text, reading comprehension, think pair share.

\section{Introduction}

English is the foreign language in Indonesia, which is taught from Elementary level to University level. It means that Indonesian people do not speak English in their daily communication. English is also used as international communication, in written as well as in spoken communication. However, the need of English is getting greater and greater in this globalization era. Most of technological advances and information are presented in English. There are many books of 
science, technology, art, article, and other published issues are written in English. Basically, there are integrated skills to be mastered in English language such as: Speaking, Listening, Reading, and Writing. Therefore, nowadays, learning English is important for people in this universe to survive successfully.

Knowing the importance of English, the Indonesian government has already made English as a compulsory subject in its educational system for junior and senior high school, even it has final examination every year. However, now there are many elementary schools which have made English as their local content subject. They are likely to prepare the students to be familiar with English. By providing English in their curriculum, they hope the students will not get some difficulties when they listen, speak, read, and write.

Teaching for English is not easy for teachers. A teacher must face different characteristics of students in his/her classroom. He should be aware of the coming problem caused by the different characteristics of the students. Therefore, the teacher needs to have an adequate knowledge, and skills which can lead him to find the appropriate strategy in teaching his students. Moreover, it has been stated in the new curriculum which is called Kurikulum 2013 revision that schools require the teacher's responsibility in developing the syllabus of his/her subject. Teaching English in class at Senior High School should not just wait and sit quietly and pay full attention during the lesson without doing anything. They tend to be active in learning. Therefore, teacher needs to have strategies in teaching them.

To be an easy in a learning, the researcher chooses student's reading comprehension on narrative text. By assumption that the comprehension of reading is the result of student's product by directed reading and using think pair share method of teaching that can be known clearly. Sofyan (1999) stated that narrative is a story that is connected some events based on the plot. Then why the teachers use narrative text, it is because the narrative as a story of human experience, so that the students easily understand the narrative text. Narrative text is a story with some complications or problematic events and it tries to find the resolutions to solve the problems Sugeng and Bambang (2018). An important part of narrative text is the narrative mode, the set of methods used to communicate to the narrative is a process narration or description. 


\section{The Definition of Reading}

To understand the problem in this research and to avoid the meaning of the term used in this research, the writer would like to make clarification of the key word of the research title. Reading is an important skill that must be learning by students to gain information. Reading is an interactive action between a reader and a text that brings spontaneously in understanding the meaning and relating it with his/her previous knowledge Alyousef (2005)

Reading is a process of getting and understanding information from the text. Reading process occurs as the readers connect with the words and illustrations provided by the author. Reading is a process of getting and understanding information from the text. Reading process occurs as the readers connect with the words and illustrations provided by the author. The readers connect ideas across sentences and paragraphs; the readers form images and predict where the author is taking them (Ogle, 2008).

\section{The Purpose of Reading}

According to Anderson (2003), there are seven aims of reading Reading for details and fact are reading to know what is done by the subject of the story, so by reading we know the activity from the doer; Reading for main ideas is reading to get the problem statement, so by reading we know the problem is in; Reading for sequence of organization is reading to know each part of the story and we understand each part of the paragraph; Reading for inference is reading to know what is the meant by in the story; Reading for classifying is reading activity to find unusual thing; Reading for evaluating is reading to know the value of the story or we understanding the moral value; Reading for comparing or contest is reading to compare the way of life of the story with the way of life of the reader, so we know the difference the way of life of the story and the reader. So that from the purposes of reading above, we can conclude that we know and understand what the topic we read, so we know the problem from the text and get how to solve it or maybe we can get the underlined the topic. 


\section{Reading comprehension}

Reading comprehension is one of the important skills to master besides writing speaking and listening skills. It is extremely useful to help the students to understand English text. Reading comprehension is very essential in reading process. In other side, reading comprehension also the ability for students to read a text, the process about understand its meaning.

Reading comprehension is the understanding of information and idea through the interaction between reader and the author from a certain kind of text. The whole purpose for reading is comprehending the text to get the information. Reading comprehension is the ability to understand the text, understand its meaning and to integrate it with what the reader already knows.

\section{The Components of Reading Comprehension}

Reading comprehension is also as a multi component, complex process that involves many interactions between the reader and the text. According to Langan (2002), there are several skills in reading comprehension, namely: Vocabulary in content: to get the purpose and mean of the text; Subject or title: to know the information of the story; Main idea: to get the problem statement; Specific Information: to know what is done by the subject of the story; Inferences: to know what is the writer meant by the story.

There are six types of comprehension strategies according to Harvey and Goudvis (2000) Make connections; Ask Questions; Visualize; Determine Text; Make some Inferences; Synthesizes.

\section{Narrative Text}

A narrative text is a text which is an imaginative story to entertain the reader as stated by Grace (2016). Narrative text has generic structure to identify, namely: Orientation: It is about the opening paragraph is in the story of the text. In orientation tells where the characters of the story are introduced. It is consisting of characteristics who is in the story, place, and when it is happened in this story. Complication: The problems in the story developed. The problem is happened when it is happened and developed. Resolution: The problems in the story is 
solved. How the problem is happy ending or bad ending. Coda/reorientation (optional): the lesson that we can get from the story

\section{The Directed Reading-Think Pair Share}

Think-Pair-Share (TPS) is one of the techniques that is expected to be a good answer for the teacher to increase the student's reading comprehension especially in narrative text. Simon in Sormin (2012) defines that most activities in Think-PairShare require the learners to solve some problems in cooperative way. This technique gives the opportunity for the students to work alone and in a group by following the steps. According to Kagan in Sugiarto and Sumarsono (2014), there are five steps in TPS technique, those are: (a) organizing the students into pairs; (b) posing the topics /questions; (c) giving time for the students to think; (d) asking the students to discuss with their pairs; and (e) calling on some pairs to share their ideas in front of the class. Thus, this technique is beneficial to improve students' comprehension in reading. However, in order to find a new insight that might be taken as a guideline for the implementation of TPS technique, the researcher would find out the students' constraints during the implementation of this technique.

Think Pair Share (TPS) is a technique that starts by asking a question, students are asked to think to answer its question, and the look for pairs to help each other and finish the answers to the whole class. This technique more provides opportunities for students to work by themselves and they are required be able to share their own ideas to their friends with the results that the students are more active in the learning process in the classroom. There are some steps in teaching reading by Think Pair Share; Step One: Teacher poses a question. First of all teachers pose a question or an issue associated with the lesson. Step Two: Students think individually. From the teacher, students are given a limited of time to think of their answer to the problematic question.

The time should be decided by the teacher based on knowledge of the students, the question, and the demands of the schedule. It may helpful, though it is not required, to have students write out their individual responses and solutions. Students should understand that while there is may be no one right answer, it is 
important that everyone come up with some reasonable answer to the question. Step Three: Each student discusses his or her answer a fellow to student. The end of the think step, the students to begin working with one other student to reach consensus on an answer to the question. Each student has a chance to try out possibilities now. Together, each pair of students can reformulate a common answer based on their collective insights to possible solution to the problem. At times, the process can go one any step farther by asking pairs of students to regroup into four some to further refine their thoughts before sharing with the group at large.

This small groups setting is threatening to each student then forwarding before the whole group with an untried answer. The pair step in the model also promotes much more conversation among students about the issues entitled by the question. Students share their answer with the whole class. In this final step, individuals can present solutions individually or cooperatively to the class as a whole group. Some pairs of students have constructed their answers, each member can take credit for the product of their thinking.

\section{The Procedures of Think Pair Share}

Think Pair Share one of cooperative learning model is a learning model that is more focused on thinking in pairs that can make students easy to interact with others, respect any differences and students can be responsible for learning. The Think Pair Share learning model provides students with the opportunity to work independently (thinking) to develop self-esteem and work on the issues presented and to collaborate with others in small groups (pairing) thus creating student confidence. In this case the optimization of student participation can be seen so that spontaneous answers appear that can contribute to the group that is being confronted. So here the teacher acts as a guide, facilitator, and motivator

Difficult students will be helped, and difficult material will be easier for students to understand so completeness in the learning process can be achieved. Think Pair Share is subject that can be one of the appropriate learning models in teaching students to think independently and be responsible for the material they 
receive So that the learning model can be implemented well, the implementation can follow the steps in applying this learning model.

Thinking, the teacher asks questions or issues related to the subject matter, then students are asked to think about these questions or issues independently for a few moments. Pairing, the teacher asks students to pair up with other students to discuss what they have thought at the Thinking stage. Interaction at this stage is expected to be able to share answers if a question or idea has been raised if a specific problem has been identified to produce an answer. Usually, the teacher gives 4-5 minutes to pair up. Sharing, the teacher asks students to share answers with the whole class about what they have talked about. This is effectively done by taking turns pair by pair continuing until about a quarter of the total number of couples have the opportunity to present or report the results of the discussion or findings (Fathurrahman, 2015).

\section{Method}

This chapter discusses about the method and the procedure of the research that would be used to answer the problem of the research in the previous chapter. The procedures consist of research type and approach (quantitative research), research setting (the time and place of the research), population and sample, design and definition of operational variable, validity and reliability test of the research instrument, technique of data collection and technique of data analysis. In this research is Classroom Action Research (CAR, the research deals with two main problem: how to describe the Student's Reading Comprehension on Narrative Text Through Directed Reading and the implementation of Think Pair Share (TPS) At MA Manahijul Huda Ngagel. To answer the problem, the researcher uses the qualitative approach to gather the required data and analyze the data.

The location of the research is Islamic Senior High School in Pati, Central Java. There are three study programs; they are science program, social program, and religion program. The subject of this research is the students on the first semester of the tenth grade (X-MIA, X-IIS, X- IIK). The students are in the class consisted of 99 students. 
This study is conducted to get information about the Improving Student's Reading Comprehension on Narrative Text Through Directed Reading and Think Pair Share (TPS) At MA Manahijul Huda Ngagel. It is also aimed to search the effectiveness of using the activity to improve student's comprehension on narrative text to learn English more intensive. In this study, a group of people taken as the subject is the students in class in the tenth of MA Manahijul Huda Ngagel in the academic year of 2019/2020. The class consists of thirty students.

Based on the problems, the appropriate method used in this research is classroom action research. This research can be defined as a research that finds the answer to solve the problems found in the classroom and make improvement on any plausible settings. This method gives the systematic

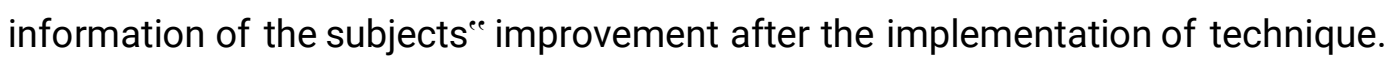
The technique is applying to teach well and innovating learning. Manion \& Morrison (2007) stated that action research is "learning by doing". It means a group of people can identify a problem, do something to resolve it, see how successful their efforts, and if it is not satisfied, it can try again. Action research is not about learning way we do or finding all certain things, but rather how we can do things better. It involves their skills, techniques, and strategies of people working.

Besides observing the classroom activity, the writer also gives questionnaire to the students and interviews the teacher as the supporting data. The description of method of Manion \& Morrison (2007) collecting data, source of data and the instrument of the study.

One of the activities of the researcher to get the maximum result, is that the researcher should explain the technique he used for obtaining the data. Therefore, the writer needs to point out the techniques of data collection which are used as the source of the writing of this study. There are three techniques of data collection in this research.

\section{Observation}

In this section, the writer is going to discuss one of the techniques in collecting the data in this study, observation. The observation technique is based on the direct experience. In this case the researcher himself can observe the subject of the 
study directly. Therefore, he can identify everything during the observation. The observation technique allows the researcher himself to see and observe and then to take some noted on the behavior changes and what happens during the observation. The observation helps the observer to get a reliable data because he acquires the data by himself without other's interference.

\section{Interview}

Another technique for gathering the data used in this research is interview. Ali (1987) defines interview as one of technique for acquiring the data by asking some questions whether directly or indirectly. Direct interview is held by interviewing people who act as the data without any media, whether about himself or everything dealing with him to collect the required data. On the other hand, indirect interview is held by interviewing someone about the subject being observed. Interview can be said as an effective device for gathering the data.

From the interview, hopefully, the writer could figure out the real situation that lies before me. There were ten structured (closed) questions that should be responded by all the students in this interview.

\section{Questionnaire}

The writer give questionnaire to 30 students to seek their opinion about reading comprehension that is given by the teacher. It is also designed to find out whether they are motivated to learn English through this activity or not. The questionnaire is written in Indonesian language so that they will clearly understand each of the questions. It consists of twelve questions. The students are not required to write their names, so they feel free to answer the questions without any pressure. The result of the questionnaire is presented qualitatively using descriptive percentage to support my research and to find out whether reading comprehension give positive effect to the students or not. The questionnaire is written in English language, the writer reports the result in English.

This research was conducted by applying Classroom Action Research and the subject of the research was the tenth class-MIA of madrasa Aliyah Manahijul Huda Ngagel at academic years 2019/2020. The number students were 30 . The research 
design was Classroom Action Research. Kunandar (2008) Classroom Action Research is an action research conducted by teacher as well as the researcher in their class with planning, action, observation, and reflection that aim to improve the quality of the learning process through cycle. The data were taken from the student's writing test, observation sheet, interview, and diary notes. The implementation as stated by Muchit (2009) is as follows; Planning, including fix the material of lesson and schedule about the time is done the research ( It was from July to October 2019), Action, including all of process study and learning about reading comprehension on narrative text through directed reading and think pair share, Observation, observation is done with the same time of the process of learning, including student's activity, the improvement material or narrative text, and the result or the value of students, Reflection, including analyses of the result of learning and arrange the planning repair or improve the next cycle.

\section{Result}

The result of this research, we can see from the table 1.

Table 1. The Improvement Reading of Each Aspects

\begin{tabular}{lccc}
\hline Aspects Of Reading & Pretest (\%) & Posttest (\%) & Increase (\%) \\
\hline Main Idea & 77.5 & 80.4 & 2.9 \\
\hline Specific Information & 57.5 & 75.8 & 18.3 \\
\hline Subject & 63.4 & 79.2 & 15.8 \\
\hline Inference & 55.9 & 72.5 & 16.6 \\
\hline Vocabulary & 76.7 & 92.3 & 15.6 \\
\hline
\end{tabular}

The implementation of Think Pair Share can improve all aspects of reading. The aspects of reading that improve the most is Specific Information with increase $18.3 \%$, and the second is Inference with increase $16.6 \%$, then Reference improves $15.8 \%$, followed Vocabulary by $15.6 \%$ and Main Idea $2.9 \%$. This research has purpose to find out whether there is any significant improvement of student's reading comprehension after being taught through directed reading and think pair share technique. The student's score of pre-test and post-test 1 and 2 increased that it determined student's improvement and good achievement in reading comprehension. 
On the other hand, the researcher did not only analyze the improvement of the student's reading comprehension achievement, but also included the increase of each aspect of reading comprehension. Therefore, it makes the result of this research is deeper and more specific in reading comprehension on narrative text.

\section{Discussion}

Based on the result of the pre-test and post-test above, it shows that there is an increase of the student's reading comprehension. The result of the data that is showed on the graphic, it can be seen there is a significant improvement of student reading comprehension after being taught through Think Pair Share technique. After the implementation of directed reading and Think Pair Share technique students could improve the reading comprehension on narrative text. This technique provided the students for three basic steps that facilitated the students in developing in their mind to think and pair on narrative text.

Those three basic steps provided the students to gain more information. In "Thinking Step", the students read the text and found some information of the text by themselves. In the next step which was "pairing step", the students combined the information of the half text to another half text to get the whole information. In the last step, "sharing step", the students with another pair collected the whole information to suit all the information to be the fixed one. From those steps, it can be assumed that this technique provided the students in obtaining more information. So that is why "Finding Specific Information" is the aspect that improve the most among other five aspects of reading. Beside that to know the result of reading comprehension's student on narrative by directed reading and using think pair share, be follow:

The result showed the increasing of the student's score from the cycle 1 to cycle 2 . In cycle 1 , the score was still low, and it was needed to do the cycle 2 . Then after giving action in cycle 2 , the result of the score increased significantly from the cycle 1 . It meant that the action which done successfully increased the student's achievement in reading narrative text by using Think Pair, Share strategy. It was supported by the fact that the mean of the score has increased in the cycle 2 , the mean in the pre-test was $63,33 \%$, and the mean of cycle 1 was $74,33 \%$. Then the mean of cycle 2 was $84,17 \%$. The students who got up 75 also grew up. In the 
pre-test, students who got up 75 were only 5 of 30 students $(16,67 \%)$. In the post test of cycle 1 , students who got up 75 were only 17 of 30 students $(56,67 \%)$. It means that there was improvement about $40 \%$. In the post test of cycle 2 , students who got up 75 were 24 of 30 students (80\%). The improvement was about $23,33 \%$. The total improvement of the student's score from the pre-test to post test of cycle 2 was $63,33 \%$. So, the result of the research showed that directed reading and Think Pair Share strategy significantly improved student's reading comprehension on narrative text.

The result of this research is also in line with (Rohibah, 2013). She had a research on increasing student's reading comprehension through TPS technique in procedure text at the first grade of senior high school. She found that teaching reading through Think Pair Share technique can be used to increase student's participation in contributing the group work clearly and has a positive result in teaching learning activities in the class. The relationship's students become stronger. Besides, students agree that think pair share technique is enjoyable, simple group work and able to improve the responsibility. All the three steps were useful in helping students to comprehend the text especially narrative text.

As it has been noted, researcher found that students reading comprehension could improve after the implementation of Think-Pair-Share technique since it gave the students not only time to think and develop their idea in "thinking step", but also gave the students opportunity to have pair discussion in "pair" and "sharing step" to discuss the text and solve the problem together. Shortly, this technique is successfully able to improve students reading comprehension. Think Pair Share technique also made students easy to comprehend the text.

\section{Conclusion}

The reading comprehension's students of MA Manahijul Huda, we can see from the components or aspects reading comprehension, they are: Vocabulary in content, Subject or title, Main idea, Specific Information, Inferences. The aspects of reading that improve the most is Specific Information with increase $18.3 \%$, and the second is Inference with increase $16.6 \%$, then Subject improves $15.8 \%$, followed Vocabulary by $15.6 \%$ and Main Idea $2.9 \%$. The implementation of reading comprehension on narrative text, it concluded that, there are five steps in TPS 
technique, those are: (a) organizing the students into pairs; (b) posing the topics /questions; (c) giving time for the students to think; (d) asking the students to discuss with their pairs; and (e) calling on some pairs to share their ideas in front of the class. As the implementation there is a significant improvement of students' reading comprehension after being taught through Think Pair Share technique. This technique provided the students the three basic steps that facilitated them in developing their mind. Reading comprehension on narrative text through directed reading and think pair share could improve the student's achievement in reading comprehension of narrative text, especially for students at tenth of class-MIA, at madrasah Aliyah Manahijul Huda Ngagel. So, the conclusions are drawn as follows: There is an improvement of the student's achievement in reading narrative text if it is taught by using Think Pair Share (TPS) strategy and directed reading. It is proven from the mean of the student's score in three tests: pre- test $(63,33)$, posttest I $(74,33)$, posttest ॥ $(84,17)$, the observation and interview sheet indicate that there is improvement in student's achievement in reading comprehension. Furthermore, Think Pair Share (TPS) as the strategy makes students can be actively, enthusiastic, and joyful to develop in teaching reading process, the result of qualitative and quantitative show that the application of Think Pair Share strategy improves the student's achievement in reading narrative text.

\section{Acknowledgement}

The writer expresses thank you to Pusat Penelitian dan Pengabdian Kepada Masyarakat (P3M) STAIN Kudus and Religion Ministry Republic of Indonesia that gave the great chance to her to conduct the research in 2019 and Madrasa of Manahijul Huda Ngagel as the setting of the research.

\section{References}

Ahmad, S. (1999). Mari Mengangkat Martabat Bahasa kita Bahasa Indonesia (Buku Pelajaran untuk SMU kelas III). Grafindo Media Pratama.

Ali, M. (1987). Guru Dalam Proses Belajar Mengajar. Bandung: Sinar Baru Algesindo.

Alyousef, H. . (2005). Teaching reading comprehension to ESL/EFL learners. The Reading Matrix, 5(2), 143-154.

Anderson. (2003). Scroling, clicking and reading. 
Fathurrahman, M. (2015). Model-Model Pembelajaran Inovatif. Yogjakarta: ArRuzz Media.

Grace, S. and E. (2016). Pathway to English for SMA/MA Grade X, Kurikulum 2013. Jakarta: PT Erlangga.

Hartina. (2008). Pengaruh model pembelajaran kooperatif tipe think pair share terhadap hasil belajar kimia kelas XI IPA SMA Negeri 5 Makassar (Studi pada materi laju reaksi). Makassar UNM.

Harvey, Stephanie, and A. G. (2000). Strategies That works: Teaching Comprehension to Enhance Understanding. Portland, Maine: Sten House.

John, L. (2002). English Skills with Readings 9th Edition. Connect Writing.

Kagan, S. (1994). Cooperative Learning. San Clemente, CA: Kagan Publishing.

Manion, Louis Cohen Lawrence \& Morrison, K. (2007). Research Methods in Education: 5th Edition. London and New York: The Taylor \& Francis e-Library.

Muchit, S. dkk. (2009). Classroom Action Research. Semarang: RaSAIL Media Group.

Ogle, B. \&. (2008). Reading Comprehension Strategies for Independent LearnersSecond Edition. New York: The Guilford Press.

Rohibah. (2013). Increasing students' reading comprehension trhough think-pairshare technique in procedure text at the first grade of sman 1 bandar sribhawono. University of Lampung.

Sormin, F. F. (2012). Improving Students' Achievement in Reading Comprehension through Think Pair Share Technique. GENRE Journal of Applied Linguistics of FBS Unimed.

Sugeng, Bambang, D. (2018). Contextual English for grade $X$ of Senior High Schools, Kurikulum 2013 Edisi Revisi Terbaru. Solo: PT Tiga Serangkai Pustaka Mandiri.

Sugiarto, D., \& Sumarsono, P. (2014). The Implementation of Think-Pair-Share Model to Improve Students' Ability in Reading Narrative Texts. International Journal of English and Education, 3(3), 206-215. 